\title{
Leaf Protein Concentrate as a Protein Source in Diets for Carp and Rainbow Trout
}

\author{
Chinkichi OgINo*1, Colin B. CoweY*2, and Jiing-Yum CHIOU*1 \\ (Received July 18, 1977)
}

\begin{abstract}
The nutritional quality of a leaf protein concentrate (LPC) prepared from rye grass was investigated by feeding experiments with carp and rainbow trout. The feeding experiments were carried out with diets in which the protein component consisted of either LPC or casein alone or with various combinations of these materials. Digestibility of the LPC was high $(86 \%)$ and the digestibility of the protein in diets containing both LPC and casein was generally greater than $90 \%$. Values for protein efficiency ratio (PER) and net protein utilization (NPU) of LPC, determined in experiments of 15 days' duration (carp) and 17 days' duration (rainbow trout), were also relatively high and were clearly improved by combination with casein. In particular, higher PER and NPU values were obtained with carp given a diet containing a mixture of LPC ( $43 \%$ of total protein) and casein ( $57 \%$ of total protein) than when either protein was fed singly. Relatively good growth rates of carp given diets containing LPC were maintained in experiments lasting 40 days. The experiments with rainbow trout demonstrated that at least $40 \%$ of the dietary casein may be replaced with LPC without reduction in PER, NPU or growth rates.
\end{abstract}

Studies on new protein sources for fish are significant from the viewpoint of economy of valuable animal products. Among plant protein sources, leaf protein concentrates (LPC) extracted by mechanical processes show a narrow range of variation in amino acid content suggesting that protein of a uniform composition may be extracted from a wide variety of green leaves ${ }^{11}$. From a feedstuff viewpoint this protein has a favourable balance of amino acids only methionine and lysine beeing consistently lower than in animal products $^{13}$. Cowey et al. ${ }^{2 !}$, however, reported that weight gain in the marine flatfish, Pleuronectes platessa, fed diets containing both leaf protein and cod meal in various ratios decreased as the proportion of plant protein in the diet increased.

The present study was conducted to examine the nutritional quality of a LPC by feeding experiments using carp, Cyprinus carpio, and rainbow trout, Salmo gairdneri, as test animals. The evaluation of the nutritional quality of the LPC was made by comparison with casein.

\section{Materials and Methods}

Protein Source

The LPC, prepared from rye grass was a gift kindly supplied by Dr. A. A. Woodham, Rowett
Research Institute, Bucksburn, Aberdeenshire. The chemical composition of the LPC is shown in Table 1. The sample contained $57 \%$ crude protein and relatively large amounts of lipids. The amino acid contents of the LPC and casein are shown in Table 2 and the principal fatty acids and minerals in the LPC are shown in Tables 3 and 4 .

\section{Composition of Test Diets}

LPC was evaluated as a protein source by feeding it either alone or in combination with casein. The composition of the test diets for carp and rainbow trout is shown in Table 5. The feeding trials were conducted with diets containing $40 \%$ protein $(\mathrm{N} \times 6.25)$ in the case of rainbow trout, and both $40 \%$ and $30 \%$ protein in the case of carp. Diets were supplied to the fish in the form of pellets.

\section{Feeding Procedure}

Experiments were conducted in glass aquaria $(30 \times 30 \times 45 \mathrm{~cm})$ using aerated, running, dechlorinated city water. Fish were trained to accept the artificial diet for some days before the experiment started, they were then fed 3 times daliy, 6 days a week on a rigid schedule. The average weight of the fish used was $2.5 \mathrm{~g}$ (carp) and $3.5 \mathrm{~g}$

*1 Laboratory of Fish Nutrition, Tokyo University of Fisheries, Konan 4, Minato-ku, Tokyo (荻野珍吉 - 邱 景雲: 東京水産大学).

*2 Institute of Marine Biochemistry, St Fittick's Road, Aberdeen, AB1 3RA, Scotland, U.K. 
Table 1. Chemical composition of the leaf protein concentrate

\begin{tabular}{lr}
\hline Moisture & $5.4 \%$ \\
Crude protein & 57.7 \\
Crude lipid & 20.6 \\
Crude ash & 3.7 \\
Crude fibre & 1.7 \\
NFE* & 10.9 \\
\hline
\end{tabular}

* Nitrogen free extract.

Table 2. Amino acid composition of the leaf protein concentrate and casein ( $\mathrm{g}$ amino acid/16 $\mathrm{g} \mathrm{N}$ )

\begin{tabular}{lrr}
\hline \multicolumn{1}{c}{ Amino acid } & LPC & Casein \\
\hline Alanine & 6.8 & 3.4 \\
Arginine & 6.5 & 4.1 \\
Aspartic acid & 10.1 & 7.8 \\
Cystine & 0.9 & 0.3 \\
Glutamic acid & 12.6 & 20.0 \\
Glycine & 5.9 & 2.0 \\
Histidine & 2.3 & 3.3 \\
Isoleucine & 5.0 & 5.6 \\
Leucine & 9.5 & 10.2 \\
Lysine & 6.6 & 8.6 \\
Methionine & 1.8 & 2.3 \\
Phenylalanine & 6.3 & 5.7 \\
Proline & 5.1 & 12.9 \\
Serine & 4.5 & 5.9 \\
Threonine & 5.0 & 4.4 \\
Tryptophan & 1.5 & 1.2 \\
Tyrosine & 4.1 & 5.1 \\
Valine & 6.5 & 6.7 \\
\hline
\end{tabular}

(rainbow trout).

Determination of Digestibility, Protein Efficiency Ratio (PER) and Net Protein Utilization (NPU)

Digestibility of dietary proteins was measured by an indirect method in which chromic oxide was used as an inert reference substance. Collection
Table 3. Principal fatty acids of the leaf-lipids*

\begin{tabular}{ccc}
\hline Fatty acid & $\begin{array}{c}\text { Fatty acid in } \\
\text { total lipid }\end{array}$ & $\begin{array}{c}\text { Fatty acid in } \\
\text { polar lipid }\end{array}$ \\
\hline $16: 0$ & $21.8 \%$ & $17.1 \%$ \\
$16: 1$ & 11.1 & 8.3 \\
$18: 0$ & 1.4 & 1.4 \\
$18: 1$ & 4.0 & 6.0 \\
$18: 2$ & 10.5 & 12.0 \\
$18: 3$ & 36.5 & 46.0 \\
\hline
\end{tabular}

* The lipids were composed of $47.6 \%$ polar lipid and $52.4 \%$ non-polar lipid.

Table 4. Mineral composition of the leaf protein concentrate

\begin{tabular}{ll}
\hline $\mathrm{Na}$ & $0.003 \%$ \\
$\mathrm{~K}$ & 0.119 \\
$\mathrm{Ca}$ & 0.268 \\
$\mathrm{P}$ & 0.346 \\
$\mathrm{Mg}$ & 0.024 \\
$\mathrm{Mn}$ & 0.002 \\
$\mathrm{Cu}$ & 0.002 \\
$\mathrm{Zn}$ & 0.014 \\
\hline
\end{tabular}

of faeces and other excretory materials was as described by OGINo et al. ${ }^{31}$ Chromic oxide in both diets and faeces was determined by the method of Hurukawa and Tsukahara." The PER and NPU of the dietary proteins were determined by the methods of OSBORNE et al. ${ }^{51}$ and of BENDER and MILLER ${ }^{6}$, respectively.

\section{Results}

Growth rate, feed efficiency, PER and NPU were determined after feeding for 15 days in the case of carp and after 17 days for rainbow trout. In the experiment with carp, fish required for analysis were removed from the aquaria after 15

Table 5. Composition of test diets for carp and rainbow trout

\begin{tabular}{|c|c|c|c|c|c|c|c|c|c|c|}
\hline \multirow{2}{*}{ Diet no. } & \multicolumn{6}{|c|}{ Carp } & \multicolumn{4}{|c|}{ Rainbow trout } \\
\hline & 1 & 2 & 3 & 4 & 5 & 6 & 7 & 8 & 9 & 10 \\
\hline LPC & 70 & 50 & 30 & 0 & 50 & 0 & 70 & 50 & 30 & 0 \\
\hline Casein & 0 & 13 & 25 & 44 & 0 & 30 & 0 & 13 & 25 & 44 \\
\hline$\alpha-$ Starch & 15 & 15 & 15 & 15 & 15 & 15 & 15 & 15 & 15 & 15 \\
\hline Dextrin & 0 & 10 & 10 & 14 & 12 & 12 & 0 & 1 & 5 & 5 \\
\hline Lipid*1 $^{* 1}$ & 7 & 3 & 3 & 2 & 9 & 9 & 7 & 7 & 6 & 6 \\
\hline Cellulose & 2 & 3 & 11 & 19 & 8 & 28 & 2 & 8 & 13 & 24 \\
\hline Mineral mix.*2 & 4 & 4 & 4 & 4 & 4 & 4 & 4 & 4 & 4 & 4 \\
\hline Vitamin mix.*3 & 2 & 2 & 2 & 2 & 2 & 2 & 2 & 2 & 2 & 2 \\
\hline Crude protein content, $\%$ & 40.8 & 41.2 & 39.8 & 42.6 & 29.8 & 26.9 & 40.6 & 39.1 & 40.3 & 39.0 \\
\hline
\end{tabular}




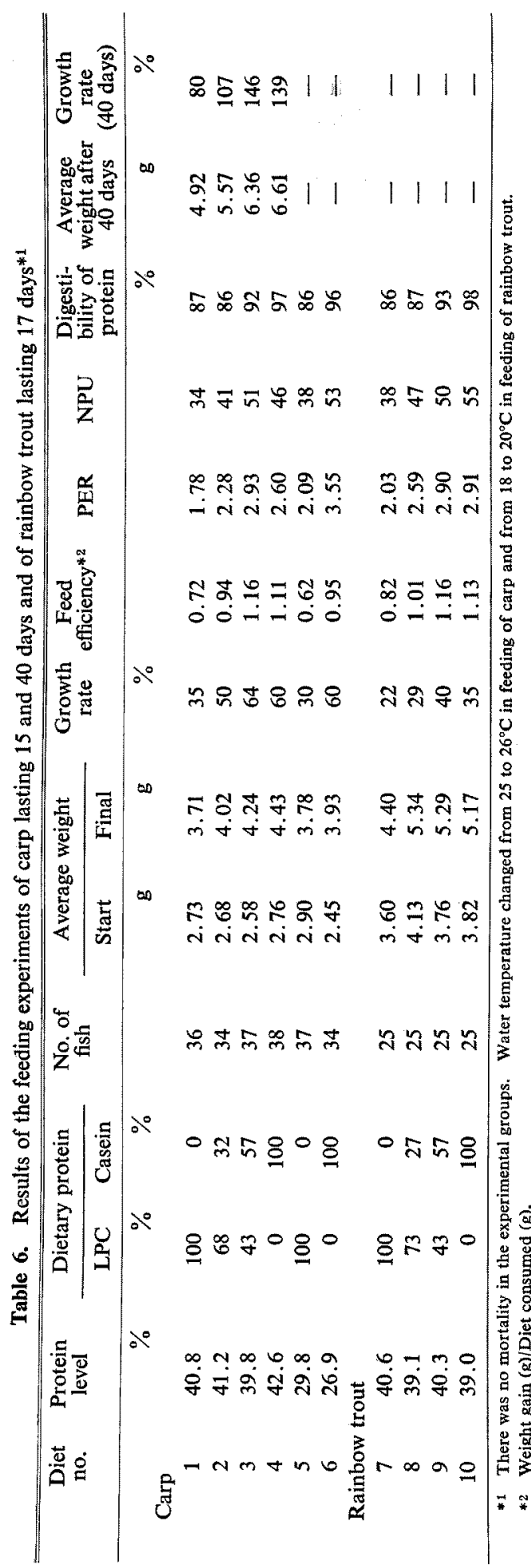

days and the remaining 25 fish allowed to continue feeding on the experimental diets for a total of 40 days. The results are shown in Table 6 and Fig. 1. Digestibility of dietary protein was determined separately using other groups of fish of average weight $8 \mathrm{~g}$.

\section{Digestibility}

Relatively high values for apparent digestibility of LPC were found in both carp and rainbow trout; there being little difference in digestibility between these species. The values obtained were lower than those found for casein which was almost completely digested. The digestibility of diets containing both protein sources decreased gradually toward the value obtained for LPC as the proportion of LPC in the diet increased.

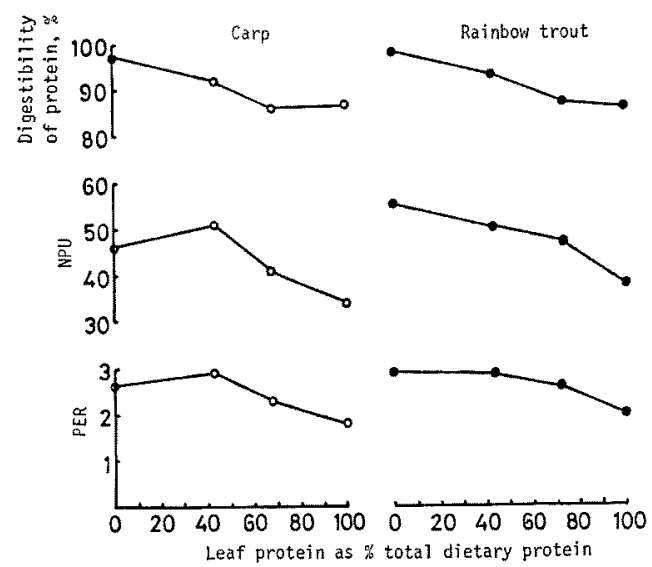

Fig. 1. Digestibility, NPU and PER for carp and rainbow trout of diets containing different proportions of LPC and casein.

\section{Growth Rate and Feed Efficiency}

With both carp and rainbow trout, growth rate and feed efficiency of fish given diets in which LPC was the sole source of protein were markedly inferior to those of fish given diets containing casein as the sole source of protein. In the case of carp this same result was obtained at both the dietary protein levels tested $(30 \%$ and $40 \%$ crude protein). However growth rates and feed efficiencies of fish given diets containing mixtures of LPC and casein were superior to those of fish given diets containing only LPC as a protein source. When the two components were used to provide dietary protein in the proportion 43 (LPC): 57 (casein) then the values obtained for these parameters were similar to or slightly higher 
than values obtained with casein as sole source of protein. This finding applied to both carp and rainbow trout.

\section{$P E R$ and NPU}

The values obtained for PER and NPU of LPC determined at dietary protein levels of $30 \%$ (carp) and 40\% (carp and rainbow trout) were markedly lower than those obtained with casein; both materials being used as sole sources of dietary protein. However, in line with the results for growth rate and feed efficiency, when mixtures of LPC and casein were used together to provide the protein component of the diet then PER and NPU values were much higher than when LPC only was used as a protein source. In particular the values obtained for PER and NPU when LPC and casein provided dietary protein in the ratio 43: 57 were very similar, for both species of fish, to those obtained with casein as the sole source of protein.

\section{Feeding of Carp for 40 days}

Table 6 also shows the results obtained when carp were given diets containing LPC for 40 days. The fish grew well on the diets but, as in the experiments of shorter duration lower rates of growth were found when LPC was used as the only protein source.

\section{Discussion}

The nutritional quality of LPC was evaluated by determining digestibility, PER and NPU together with growth rate and feed efficiency using carp and rainbow trout.

The values for digestibility, PER and NPU of LPC ( $100 \%$ of dietary protein) for both species were relatively good and can clearly improved by combination with other proteins. In carp in particular, the diet containing a mixture of LPC (43\% of dietary protein) and casein (57\%) gave better PER and NPU values than did either singly (Table 6 and Fig. 1). A feature of the results obtained with rainbow trout was that at least $40 \%$ of the casein can be replaced with LPC without any loss in PER, NPU or growth rate. In both proteins, methionine might be assumed to be the first limiting amino acid (Table 2). However, it does appear that the overall balance of amino acids in a combination of the two proteins is equal or superior to that in casein (the better of two proteins) alone. It may be that some other amino acid (arginine, threonine and tryptophan are possibilities) is limiting in the casein and this possible limitation is improved by combination with LPC. Although the growth rate of carp during a 40 day period on a diet containing LPC as the only protein source was inferior to casein, the fish showed a good appetite and there was no mortality. These results indicate that LPC can be used satisfactorily as a protein sorce for carp and rainbow trout in combination with other proteins having good nutritional quality. The use of LPC as sole source of dietary protein might also be possible especially in omnivorous fish such as carp and Tilapia.

Fatty acids of the LPC-lipids were mainly linolenic, palmitic, palmitoleic and linoleic acids together with small amounts of saturated and mono-unsaturated acids. Thus LPC is potentially useful as a source of the essential fatty acids of these fish ${ }^{8-101}$. Finally, as shown in Table 4, LPC provides a useful supplement of minerals required by the fish. ${ }^{11}$

\section{References}

1) E.D. Gerloff, I. H. Lima, and M. A. Stahmann: J. Agr. Food Chem., 13, 139-148 (1965).

2) C. B. Cowey, J. A. Pope, J. W. Adron, and A. Blair: Mar. Biol., 10, 145-153 (1971).

3) C. Ogino, J. Kakino, and Mao-Song Chen: Bull. Japan. Soc. Sci. Fish., 39, 519-523 (1973).

4) A. Hurukawa and H. Tsukahara: Bull. Japan. Soc. Sci. Fish., 32, 502-506 (1966).

5) T. B. Osborne, L. B. Mendel, and E. L. Ferry: J. Biol. Chem., 37, 223-229 (1919).

6) A. E. Bender and D.S. Miller: Biochem. J., 53, vii (1953).

7) J. E. Halver and J. A. Coat： Progr. Fish-Cult., 19, 112-118 (1957).

8) J. D. Castel, R. O. Sinnhuber, J. H. Wales, and D. J. LEE: J. Nutr., 102, 77-86 (1972).

9) T. Watanabe, C. Ogino, Y. Koshisht, and T. Matsunaga: Bull. Japan. Soc. Sci. Fish., 40, 493-499 (1974).

10) T. Takeuchi and T. Watanabe: Bull. Japan. Soc. Sci. Fish., 43, 541-551 (1977).

11) C. OGINo and H. TAKedA: Bull. Japan. Soc. Sci. Fish., 42, 793-799 (1976). 